ІМІТАЦІЙНА МОДЕЛЬ НАВЧАННЯ СТУДЕНТІВ-МАТЕМАТИКІВ У КОНТЕКСТІ ФОРМУВАННЯ ЇХНЬОЇ МЕТОДИЧНОЇ КОМПЕТЕНТНОСТІ

\title{
SIMULATION MODEL OF TRAINING STUDENTS IN MATHEMATICS IN THE CONTEXT OF THE FORMATION OF THEIR METHODOLOGICAL COMPETENCE
}

\begin{abstract}
Стаття присвячена одній з актуальних проблем підготовки майбутніх учителів математики - формуванню їхньої методичної компетентності, яка є важливою складовою частиною профессійної педагогічної підготовки вчителя. Основна увага зосереджується на дослідженні питання формування методичної компетентності студентів-математиків під час викладання курсу «Методика навчання математики» засобами імітаційних моделей у процесі навчання за індивідуальними освітніми траєкторіям. Зокрема, розкривається сутність таких понять, як «методична компетентність», «індивідуальна освітня траєкторія». Методична компетентність учителя розглядається нами як теоретична і практична готовність до проведення занять із певного предмета, що виявляється у сфрормованості системи дидактико-методичних знань і вмінь з окремих розділів та тем курсу, окремих етапів навчання й досвіду їх застосування, спроможність есрективно розв'язувати стандартні та проблемні методичні завдання. Висвітлюються прочеси: освітній, науковий та виховний, через які здійснюється зміст та організація методичної підготовки студента, структура імітаційної моделі (мотивація, інформачійно-змістовий етап, діяльнісний, творчий, рефрлексивно-оцінний), підстави технологіі проєктування освітнього процесу за типом імітаційної моделі та модульна побудова занять, що базується на принципі єдності свідомості і діяльності. Зазначається, що у прочесі навчання змінюється роль викладача: він уже не $є$ одноосібним охоронцем істини і знань, він керівник вибору індивідуальної освітньої траєкторії навчання студента і колега. Формування методичноі компетентності майбутніх учителів математики передбачає використання форм $і$ методів активного навчання, сучасних моделей керованої самостійної роботи.

Ключові слова: методична компетентність, імімаційна модель, індивідуальна
\end{abstract}

освітня траєкторія, модульна побудова занять.

The article is devoted to one of the topical problems of the preparation of future teachers of mathematics the formation of their methodological competence, which is an important component of the teacher's professional teacher training. The main focus is on the study of the methodological competence of mathematicians in the course of reading the course "Method of teaching mathematics" by means of simulation models for studying on individual educational trajectories. In particular, the essence of such concepts as "methodical competence", an "individual educational trajectory" is revealed. The methodological competence of the teacher is considered by us as a theoretical and practical readiness for conducting classes on a certain subject, which is manifested in the formation of the system of didactic-methodical knowledge and skills from separate sections and themes of the course, separate stages of training and experience of their application, the ability to effectively solve standard and problem methodical tasks. Processes are highlighted: educational, scientific and educational, through which the content and organization of the student's methodical training is carried out, the structure of the simulation model (motivation, information-content stage, activity, creative, reflexive-evaluation), the basis of the technology of designing the educational process by the type of the simulation model and the modular construction of classes based on the principle of unity of consciousness and activity. It is noted that in the process of learning the role of teacher changes: he ceases to be the sole guardian of truth and knowledge, he is the leader of the choice of the individual educational trajectory of student and colleague training. Formation of methodical competence of future mathematics teachers involves the use of forms and methods of active learning, modern models of controlled independent work.

Key words: methodological competence, simulation model, individual educational trajectory, modular construction of classes.
Постановка проблеми в загальному вигляді. Кардинальні зміни соціально-економічного укладу життя України призвели до зміни методологічних пріоритетів в освіті, появи і поширенню нових освітніх парадигм.

Відбувається формування нової фрілософрії освіти, у якій загальнолюдські цінності, сама людина як головна суспільна цінність висувається на перший план. Становлення такої системи освіти неможливе без підготовки для неї фрахівців нового покоління, передусім учителів як головного стратегічного і технологічного ресурсу її вдосконалення. Саме від того, яким буде вчитель, від його морального, інтелектуального, культурного та профресійного потенціалу залежить майбутнє освіти.
У сучасних умовах, з урахуванням соціокультурних і освітніх тенденцій, поняття якості освіти поглиблюється, наповнюється новим змістом. Так, основним критерієм якості професійної підготовки «у сучасному розумінні $€$ розвиненість у випускника здатності застосовувати сорормовані компетенції для ефективного вирішення різноманітних соціально-професійних завдань, зокрема високого рівня складності» [3, с. 7].

Важливою складовою частиною профресійної педагогічної підготовки вчителя є методична. Сорормованість психолого-педагогічних знань і умінь виступає фрундаментом, на якому фрормуються методичні знання, уміння і навички. Систему навчання студентів методичних знань, умінь 
і навичок А. Новік визначає як малу систему методичної безперервної підготовки (щодо системи профресійної підготовки) студентів до роботи вчителем математики [4, с. 34].

Аналіз останніх досліджень і публікацій. У дослідженнях останніх років велика увага приділяється частковим видам професійно-педагогічної компетентності, у яких розглядається методична (В. Адольф, І. Акуленко, М. Бибик, А. Кузьмінський, А. Пометун, С. Раков, Н. Тарасенкова й ін.) або дидактично-методична (Л. Коваль, Т. Руденко) компетентність. Дослідники описують методичну компетентність, пов'язуючи її з викладанням конкретного навчального предмета.

Виділення не вирішених раніше частин загальної проблеми. У науковій літературі роглядається фрормування методичної компетентності вчителя математики (І. Акуленко, А. Кузьмінський, І. Малова, В. Моторіна, Н. Тарасенкова й ін.) різними методами і засобами. Але навчання студентів-математиків за індивідуальною освітньою траєкторією малодосліджене. Тому необхідно роглянути фрормування методичної компетентності майбутніх учителів математики засобами імітаційних моделей під час навчання за індивідуальними освітніми траєкторіям.

Мета статті - розкрити сутність, структуру профресійно-методичної імітаційної моделі фрормування методичної компетентності майбутніх учителів математики, а також технологію проєктування освітнього процесу на її основі.

Виклад основного матеріалу. Методичну компетентність учителя математики будемо розуміти як профресійну компетентність, яка виражена у практичній готовності до здійснення видів професійної діяльності, пов'язаної $з$ навчанням математики в системі загальної середньої освіти, заснованої на системі теоретичних знань. Методична компетентність учителя розглядається нами як теоретична і практична готовність до проведення занять із певного предмета, що виявляється у сорормованості системи дидактико-методичних знань і вмінь з окремих розділів та тем курсу, окремих етапів навчання й досвіду їх застосування, спроможність ефективно розв'язувати стандартні та проблемні методичні завдання.

Зміст і організація методичної підготовки студента в педагогічному університеті пов'язані 3 такими процесми: освітній, науковий та виховний, а інтеграція цих процесів $€$ необхідною умовою якості підготовки.

Формування методичної компетентності майбутнього вчителя математики засобами дисципліни «Методика навчання математики» відбувається у взаємодії виділених процесів і являє собою обмін, отже, визначає освітній простір як креативно-освітній, який будується на ідеях культурної комунікації за принципами природовідпо- відності, культуровідповідності та самостійності.

Сутність методичної компетентності полягає в єдності знаннєвої, діяльнісної й особистісної складових частин.

Для їх фрормування в освітньому процесі вишу потрібна змістовно-технологічна інтеграція всіх складників дидактичної системи навчання, комплексне ресурсне забезпечення (однією із цих складових частин є просресійна підготовка майбутніх учителів математики за індивідуальними освітніми траєкторіями).

У процесі навчання змінюється роль викладача: він уже не є одноосібним охоронцем істини і знань, він керівник вибору індивідуальної освітньої траєкторії навчання студента і колега, водночас:

- основний акцент робиться на організації активних видів навчальної діяльності;

- викладач виконує ролі педагога-менеджера і режисера навчальної діяльності;

- навчальна інорормація використовується як засіб організації навчальної діяльності, а не як мета навчання;

- студент є суб'єктом діяльності поруч із викладачем, а розвиток його індивідуальності - одна 3 головних освітніх цілей.

У контексті означеного підходу в нашій практиці фрормування методичної компетентності майбутнього вчителя математики ефективно використовується така форма організації освітнього процесу, як профресійно-методична імітаційна модель.

Імітаційна модель навчання передбачає ґрунтовне теоретичне осмислення студентами діяльності викладання математики і дослідне оволодіння видами цієї діяльності, а також відповідними методичними вміннями та професійними особистісно значущими якостями до етапу педагогічної практики в загальноосвітніх закладах.

Імітаційна модель має таку структуру:

1. Мотивація. Продуманий і організований викладачем психологічний настрій на майбутню діяльність, докладання фрізичних і духовних сил для активної праці у групі кожним студентом. Ця вступна частина заняття дуже важлива, тому що студентам належить практична, дослідна робота, що потребує цілком певної спрямованості, високого інтересу, бажання і прагнення «тут і зараз» оволодіти методичним матеріалом.

2. Інформаційно-змістовий етап. Змістовна частина занять забезпечує реальне уявлення про ту навчально-методичної ситуацію, яка повинна бути осмислена на занятті. Пропонується конкретний і яскравий образ дій, який належить осмислювати і який зазначено в темі.

3. Діяльнісний. Центральна частина імітаційної моделі. Розгортається логічний ланцюг міркувань: узагальнюються фракти, визначаються поняття, судження, робляться умовиводи, висновки ілюструються, перевіряються ігровою практикою, 
проєктуються можливі зміни перебігу і характеру реальної діяльності згідно зі зробленими висновками. Створюється проєкт майбутньої діяльності.

4. Творчий. Практикум - етап особливого інтересу для студента. Йому треба бачити практичне втілення теоретичних ідей, «тут і зараз» випробувати технологію такого втілення. Призначення практикуму - фрормування первинного, профресійного досвіду у студента.

5. Рефлексивно-оцінний. Це короткий етап осмислення значущості проведеної роботи для кожного студента. За допомогою відповіді на питання типу: «що ми робили?», «які методичні вміння та навички відпрацьовувалися?», «на який рівень освоєння вийшли за результатами діяльності?», «що важливо для майбутньої професії?», свідомість студента виокремлює сутність тієї події, що відбулася, визначає роль осмисленого явища для майбутнього.

Підставами технології проєктування освітнього процесу за типом імітаційної моделі $€$ : діалогічність; діяльнісно-творчий характер; спрямованість на фрормування індивідуального методичного стилю у викладанні математики; надання студенту необхідного освітнього креативного простору, свободи для ухвалення рішень, творчості, вибору змісту, способів діяльності і поведінки; наявність значущої для нього проблематики (виходячи 3 його індивідуальної освітньої траєкторії); значущість отриманих результатів; обов'язкове поєднання індивідуальної і групової роботи.

Одиницею освітнього процесу є модуль. Структурна побудова модуля відповідає нормативній схемі діяльності, що реалізується за допомогою блоків: цілеутворення, змістовного, діяльнісного й оцінно-реорлексивного. Перенесення нормативної схеми навчальної діяльності і її цілковите освоєння студентами є неодмінною умовою розвитку і дозволяє їм піднятися до рефлексивно-дослідного рівня діяльності, тобто самим вибудовувати траєкторію свого особистісного зростання.

Модульне побудова занять базується на принципі єдності свідомості і діяльності: тільки тоді навчальний зміст усвідомлено засвоюється, коли він стає предметом активних дій студента, причому системних. Навчальні елементи диореренційовані за змістом та рівнем пізнавальної самостійності; мають проблемний характер, орієнтують на пошук проблем і їх вирішення; відображають механізм засвоєння знань: сприйняття, осмислення, запам'ятовування, застосування, узагальнення, систематизацію, інтегруються метою модуля.

Діяльність студента проходить у зоні його найближчого розвитку; орієнтована на самоврядування, фрормує навички спілкування; дає можливість працювати в індивідуальному темпі, раціонально розподіляти свій час; реалізує рефлексивні можливості на кожному занятті.
Основна фрункція викладача за такого підходу - розробити модульну програму і зміст модулів, індивідуальні траєкторії вивчення модулів, а на занятті він мотивує, організовує, координує, консультує, контролює, тобто, використовуючи потенціал модульного підходу, здійснює управління формуванням методичної компетентності.

Під час вивчення студентами циклу дисциплін із методики навчання математики реалізуємо імітаційні моделі організації навчального процесу, що дозволяє включити до процесу навчальної діяльності системи завдань, спрямованих на моделювання ситуацій майбутньої професійної діяльності. Метою завдань є врегулювання стандартної або нестандартної ситуації за допомогою знаходження відповідного способу рішення 3 обов'язковим використанням математичних і методичних знань. Основною особливістю таких завдань є отримання професійно значущого результату для студента майбутнього вчителя математики.

Умова завдання сорормульована як сюжет, ситуація або проблема, для вирішення якої необхідно використовувати знання (з різних розділів основного предмета - математики, методики навчання математики, з іншого предмета або із життя), на які немає явної вказівки в тексті завдання. Основна мета - створення умов для входження студента у профресію вчителя математики засобами «проживання» різноманітних ситуацій на уроках, що імітуються під час проведення занять.

Оскільки професійна підготовка майбутніх учителів математики проходить за індивідуальними освітніми траєкторіями (кожний студент вибрав свою індивідуальну освітню траєкторію вивчення даного модуля, надану викладачем - Т. К.), то відповідно даються різнорівневі завдання. Вони відрізняються складністю запропонованої теми уроку, теореми, що вивчається, означення, що фрормується, психологічною характеристикою класу, рівнем навчальних досягнень учнів.

Досвід роботи свідчить про те, що використання імітаційних моделей («репетицій» педагогічної діяльності - Т. К.) дає студентам можливість не тільки «проживати» ситуацію навчально-виховного процесу на уроці, а й краще розуміти психологію її учасників, набувати досвіду поведінки в умовах педагогічної діяльності, що потребує мобільного реагування на навчальні ситуації, які виникають у школі.

Формування методичної компетентності майбутніх учителів математики передбачає використання фрорм і методів активного навчання, сучасних моделей керованої самостійної роботи.

Найбільш адекватними методами в умовах науково-дослідницької спрямованості в методичній підготовці майбутнього вчителя математики є метод проєктів і дослідницькі методи навчання, що спираються на пошукову активність студента. 
Робота над проєктами є загальною фрормою реалізації вмінь планування, прогнозування, побудови, обґрунтування і пояснення, виконання й оорормлення. Логіка освітнього процесу методичної підготовки студента базується на проєктуванні, моделюванні, конструюванні, дослідженні і всебічному оцінюванні результатів завершеного проєкту як 3 погляду його якісного і кількісного рівня, так і щодо входження в реальний навчальний процес уроку математики.

Дослідницькі методи відіграють значну роль у формуванні методичної компетентності студента, бо включення видів дослідницької діяльності в освітній процес компенсує функції наукового процесу.

Робота над проєктами з використанням пошуково-дослідницьких методів здійснюється в малих групах, де реалізується спільна діяльність. Спільне вирішення навчально-методичної проблеми розглядається не тільки як її пізнання, але і як розуміння на основі знань про майбутню професійну діяльність учителя математики. В основу кладеться не «суб'єкт-об'єктне» знання і перетворення, а комунікація - розуміння «людини в ситуації», діалог з іншим. Це сприяє розвитку мислення, вільного від крайнощів; сприяє спілкуванню для самореалізації як суб'єкта діяльності, проблематизації наявних здібностей, а також перенесенню набутих здібностей і досвіду діяльності у практику викладання математики. Уміння проблематизувати себе і свою діяльність сприяє фрормуванню досвіду самостійної навчальної діяльності студента, а потім усвідомленню потреби в постійному самовдосконаленні й самоосвіті.

Особливе значення в підвищенні якості методичної підготовки студента має інформатизація навчального процесу шляхом використання нових інформаційно-комунікативних технологій (далі - ITK).

Варто зазначити, що ITK не доповнюють традиційний навчальний процес, що склався, з їхньою допомогою, тобто на їхній базі, під їхнім впливом, ними самими, нарешті, створюється інший навчальний процес, 3 іншою цільовою орієнтацією, іншими рольовими функціями учасників, іншим середовищем навчання [5].

Під час вивчення дисциплін методики навчання математики ми використовуємо навчально-методичний комплекс, який містить:

- спеціалізований електронний навчальний посібник із дисциплін «Методика викладання математики» та «Шкільний курс математики»;

- інтерактивний довідник-глосарій за дисциплінами, що вивчаються;
- базу тренувальних професійно-методичних завдань;

- базу тестів для організації самоконтролю і самооцінки рівня методичної підготовки;

- систему моніторингу формування методичної компетентності студента.

Електронний навчальний посібник $€$ відкритою інформаційною системою і містить модулі навчального матеріалу, що відповідають навчальній програмі. Він охоплює індивідуальні траєкторії навчання кожного модуля, відповідне навчальнометодичне забезпечення і виконує завдання індивідуалізації навчання. Електронний навчальний посібник дає можливість реалізації будь-якого способу управління навчально-пізнавальною діяльністю студента; забезпечує систематичний зворотний зв'язок; дає можливість документування процесу фрормування методичної компетентності та його результатів.

Використання ITK сприяє виробленню у студентів механізмів ситуаційного реагування із залученням критеріїв інтелектуального та ціннісного типів; розвитку творчого мислення, рефлексивних дій, спільних групових дій.

Висновки. Основними цінностями активних форм навчання $€$ такі: проблематизація змісту, способів і засобів навчальної діяльності, а також наявність здібностей студента до діяльності; їх самовизначення в діяльності на дисциплінах, ядром яких є орормування методичної компетентності майбутнього вчителя математики. Навчальна діяльність студентів організується як процес розв'язання навчально-методичних проблем у вигляді профресійно-методичних завдань через виконання проєктів, що дозволяють кожному здійснювати самопізнання, самоорганізацію, самореалізацію, рефлексію і творче самовираження. Усі ці процеси в сукупності і становлять саморозвиток студента як особистості.

\section{БІБЛІОГРАФІЧНИЙ СПИСОК:}

1. Гусакосвский М. Об открытости новому опыту. AiB. 1997. № 9. С. 84-88.

2. Жук О. Педагогическая подготовка студентов: комплексный подход. Минск : РИВШ, 2003. 336 с.

3. Новик И. Формирование методической культуры учителя математики в педвузе : монография. Минск : БГПУ, 2003. 178 с.

4. Полат Е. Метод проектов. URL: http:www.itech.ru/ met/metoduka/azwn3.php.

5. Яковлев А. Инорормационно-коммуникационные технологи в дистанционном обучении : доклад на круглом столе «ИКТ в дистанционном образовании». Москва : МИА, 1999. 14 с. 